\title{
A PERSONAL APPROACH TO THE EMPLOYMENT OF TECHNOLOGY DURING THE ENGLISH COURSE
}

\section{Ramona DEMARCSEK ${ }^{*}$}

\begin{abstract}
Being in a constant struggle of trying to keep our students' interest during the English class at a time when they are bombarded with technological distractions from every platform - television programmes, smart devices, computers, laptops etc. - requires a teacher's resourcefulness and creativity, and investment of his/her time and money in materials and technology in order to keep up with the pace at which students operate on a daily basis, including in class. This paper takes a closer look at the employment of technology during the English class with students in Business Administration from the North University Center of Baia Mare, the Technical University of Cluj-Napoca. It is a case study regarding the extent to which the use of technology aids the teaching-learning process. It also tries to find the right balance between traditional teaching-learning tools and the employment of modern technology in class.
\end{abstract}

Keywords: teaching-learning process, smart technologies, e-platforms

\section{Introduction}

English teachers and English classes have always been privileged in that they had been using technology from early on. It was almost a prerequisite of the English lesson. It had soon become obvious that the pen, the notebook and the book were no longer sufficient to deliver the necessary skills. Thus cassettes and cassette players were employed for exercising the listening skill; video cassettes and video players were also used in order to watch films or documentaries in the target language, i.e. English, also with the aim of exercising the listening skill, yet in a more entertaining manner. As technology advanced, audio and video cassettes soon became obsolete and were replaced by CDs which, in turn, head toward a similar fate, with other devices, as well as internet sources, pushing them to the outskirts of in-class used technology. Moreover, technology such as floppy disks, overhead projectors or items such as transparencies are nowadays part of a defunct historical period of whose existence today's generation of students are not even aware.

\footnotetext{
* Lector univ. dr., Departamentul de Filologie şi Studii culturale, Facultatea de Litere, Baia Mare, Universitatea Tehnică din Cluj-Napoca, str. Victoriei, nr. 76, Baia Mare (ramona.demarcsek@cunbm.utluj.ro).
} 
And it is obviously not only the listening skill that is aided by the advancements in technology. When it comes to exercising the students' reading skills, books are slowly falling into disuse, being in fierce competition with e-book readers and other similar devices which not only allow for "passive" reading, but also encourage and support annotations, highlighting, note-taking and the like. This is not to say that books are soon to become obsolete, yet there seem to be many other options that appear to compete with books for the reader's time.

There exist multiple online platforms and tools which are employed during the English classes with the purpose of exercising vocabulary and grammar as well in an interactive manner. All these have changed the role of the teacher from that of the sole resource in class, to that of a moderator; students can create content themselves, under the supervision of the teacher, and thus become more involved in the teaching-learning process.

This paper takes a closer look at the employment of technology during the English class with students in Business Administration from the North University Center of Baia Mare, the Technical University of Cluj-Napoca. It is a case study regarding the extent to which the use of technology aids the teaching-learning process. It also tries to find the right balance between traditional teaching-learning tools and the employment of modern technology in class.

\section{The current situation}

At a time when society is bombarded with ever-more sophisticated devices that are meant to improve the quality of life (while at the same time keep us entertained), it is no wonder that in-class behaviour - from pupils to students - is a challenging issue for teachers who are trying to come up with solutions to keep their students' attention and interest in whatever is being taught.

In the opinion of Ken Robinson, in his Changing Education Paradigms speech delivered for Ted Talks in $2010^{1}$, "our children are living in the most intensely stimulating period in the history of the earth. They're being besieged with information and calls for their attention from every platform - computers, from iPhones, from advertising hoardings, from hundreds of television channels (...)". This is true not only for children but for every individual. It is no wonder then that under these circumstances, course attendees become distracted and that teachers have to be extraordinarily resourceful (and equally motivated) to keep their students focused on the topic being taught.

\footnotetext{
${ }^{1}$ Robinson, 2010.
} 
At present, the devices and other electronic resources that can be used during the English classes are numerous and diverse. From smart boards to smart phones, i.e. from devices meant for frontal usage by the teacher to devices meant for individual users, every technology is meant to make the lesson more entertaining, to keep participants more focused during the teaching-learning process by employing precisely those devices that are identified by Ken Robinson as distracters.

At university, such devices as video projectors and PowerPoint presentations are currently as common as paper-based books and notebooks; they are an integral part of courses, a natural occurrence in the course or seminar room. It is the use of smart devices that professors, in this particular case, professors of English, are trying to integrate in the teaching-learning process. And the term smart devices is used here quite flexibly, not only with reference to smartphones, but to any type technology used in class. There is, nevertheless, one issue with all this new technology and its employment in class: teachers are required to keep up with the evolution of technology, as well as be knowledgeable in this field; they need to be willing to step out of their comfort zone and be open to acquiring new skills, in particular those skills that are necessary in order to manage, handle and operate these smart technologies.

In previous research I spoke about the use of technology in class, i.e. the English class specifically, with the aim of improving the quality of the teaching-learning experience ${ }^{2}$, as well as about taking advantage of the students' technical abilities with the exact same purpose ${ }^{3}$. It is unquestionable that smartphones have become an every-day item so common that one cannot imagines one's own life functioning properly without it. Psychologists have carried out extended research and the conclusions are all the same: present-day society is addicted to smartphones, to being connected in the virtual environment, i.e. to social media, in short to that which we call smart technologies.

Despite the fact that the internet is still considered "new technology", it is so ingrained in our every-day lives that one cannot fathom a functional world without it. Similarly, these days the English lessons seem to depend quite extensively on the internet for resources or simply as a platform which offers access to e-learning tools. These days, using online dictionaries is common practice; very few students still own a dictionary in the traditional book format, and very many of them do not even see the point anymore in having such an old-school tool since with a click - or a simple tap, since we are talking about smartphones - they can get the meaning of a word or phrase, with synonyms, as well as context usage provided. Consequently,

\footnotetext{
${ }^{2}$ Demarcsek et. al., 2017.

${ }^{3}$ Demarcsek et. al., 2016.
} 
during the English courses that I teach, with the students in Business Administration, the use of on-line dictionaries is common practice and it has been so for a long time. By now, smartphones seem to be an extensions of one's hand, a natural appendix; thus, since students are so eager to use them, putting them to good use during the English course seemed like the simplest task.

For reading tasks, printed texts are no longer used (magazine or book excerpts, handouts or the like); instead, with so many online resources, original reading material written in native English, can be used, with students either reading the fragment online, or downloading it to their devices. This is an environmentally friendly approach to exercising reading skills, yet one should not assume that, due to this eco-friendly approach, the English classes are paper-free. We are nevertheless heading towards a paper-free future but we are not there yet. Moreover, during tasks that require teamwork, students can use social media to communicate with one another either in class, or outside it, should the task require completion outside the classroom or if its completion is set for a time span set outside the timeframe allocated to in-school activities.

Yet these types of activities are not even close to what is nowadays considered smart technologies. There exist online platforms that offer the possibility of interactive activities, where students create content themselves, communicate with one another or with the teacher etc. Blended learning is becoming almost a requirement, with Moodle platforms and the like becoming ever more prevalent in the teaching-learning environment.

\section{Case study}

What happens during the English classes that I coordinate within the North University Centre of Baia Mare, Technical University of ClujNapoca, might not be extraordinary, yet it is definitely not standard procedure. In this institution I coordinate the English activities for six groups of students attending full-time education programmes, and four groups in part-time education programmes. The total number of full-time students is 250 , while the number of part-time students is 121. All these students study Business English. The level of the groups is quite eclectic, thus making it more challenging for the teacher to meet the requirements of various students, according to their levels, the only solution being to organize them in groups according to their level and assign them appropriate tasks. This is not always feasible or achievable, yet we strive to accommodate the needs of as many of our learners as possible.

The type of technology that is available for students fall under two categories: one with technology that is considered rather common, such as video projectors, desktops or laptops, smartphones, and another category 
which includes more modern technology, such as Smart Boards, e-book readers, various notebooks, tablets and pads, smart pens, even the most state-of-the-art technology such as e-ink or digital paper tablets. Some of these devices are for the teacher's use, others are used by the students only; whichever the case, students are enthusiastic about using smart devices and the latest technology, as long as these are not overused. Students can get bored with even the most modern device if this is overused.

The most recent addition to the instruments employed during the English classes with these students is a Moodle platform. It is still at experimental level and it will take some time until it is completely operational and usable in such a way that anyone can take full advantage of its features. As for the English course, the material available is made up of twelve modules. Each module contains a text on a certain topic, followed by a set of exercises: one reading comprehension, two vocabulary exercises and two grammar exercises. The platform supports all types of exercises: from multiple choice, with the possibility to click the correct answer, to fill-ins, where students can drag-and-drop items from a given list, to open ended questions, where students can provide their own answers, and so on.

The materials available for the English course are conceived with the aim of giving students the opportunity to exercise their reading skills, learn vocabulary, practice grammar, and not so much as an assessment tool, although this feature is also available. The course being conceived in this way, it does not limit the number of attempts students have for solving the tasks. This means they can re-read the text and redo the exercises until they feel comfortable with the outcome. After each attempt, students receive feedback with regard to how well they performed. The feedback is provided automatically, yet there exists the option for the teacher to intervene and provide feedback in the "Forum" section. Moreover, the teacher can see the time when a student started the activity, how long it took him/her to finish the task, how well he/she did during every attempt, how many attempts were carried out.

There exists nevertheless the option for the teacher to time and limit the attempts. This feature is particularly useful when the platform is used for assessments. There are tools which allow the teacher to set the beginning and end date of a course or a test, others that block the students' access to parts of the course until the completion of certain previous tasks, and yet others that allow the teacher to set the timeframe for a specific test, i.e. determine how long the test is supposed to last, and other such features. When creating a test, the teacher has the possibility to select any question or set of questions from the so-called "question bank", arrange them into categories, establish the percentage for each question etc. When students complete a test, they get the final score the moment they click the "submit" button. The huge advantage is that, if all features are used properly, that can 
be the final grade - unless the teacher decides he/she will consider other tasks, project work, attendance etc. Yet as mentioned above, with the clicking of the "submit" button, the students get the final score for their test, as well as feedback, thus knowing how well they performed and on which aspects of the course they need to focus in order to perform better the next time.

The platform is not only available on computers (desktops or laptops); it can be accessed on smartphones as well, from any location, at any time, as long as there is internet connection. This might seem as a slight disadvantage of the platform when it comes to taking tests, yet there exists the option of blocking devices depending on their IPs. In other words, when students sit for an exam through the Moodle platform, the teacher has the possibility of setting the IPs which should have access to the platform, thus limiting access to only those devices that are inside the classroom at the time of the examination.

One serious downside of the e-platform is the fact it requires some above average technical skills, thus teachers using the platform need to be trained themselves in creating content on the platform; they need to attend training courses themselves in order to be able to use all the features of the platform. Consequently, this aspect generates another downside: it is only the individuals who are willing to step out of their comfort zone that will consider using this type of platform. The entire process is time consuming: it requires an initial investment in time for the training course, and then even more time for the creation of the course itself and of the subsequent tests or other tools that the platform supports. It is necessary to have the right mindset, to be willing to learn, to be willing to invest all that time, to have a certain understanding of how e-platforms work, and have a certain level of technical skill, but when the whole process is complete and everything is available on the platform, the job of the teacher is much easier, and there is much time saved with the grading process in that it is eliminated almost completely, should one rely on the e-platform for that task.

Since it gives unlimited access to students from anywhere, at any time, the employment of the Moodle platform is not restricted to the classroom environment. On the contrary, it is actually extremely useful for students who for objective reasons cannot be in class for every course or who want to improve whilst exercising on their own, at their own pace, when they feel more attuned with the topic. It is especially suitable for students in part-time education programmes, yet without being exclusively addressed to them.

As previously mentioned, at this point, the e-platform is employed as an experimental tool during the English classes I am coordinating. In order to be able to assess the usefulness of the instrument, I designed a simple questionnaire addressed to the students who had been part of the 
experiment, asking them to grade their experience on the platform on a scale from 1 to 5, with 1 being the lowest degree of satisfaction and 5 the highest. The questions were: 1 . How do you feel about the use of the platform as a learning instrument?, 2. How useful do you consider the platform in the learning process?, 3. How would you grade your evolution in terms of language skills? There was also a forth question - a yes/no question meant to find out if students were interested in continuing to use the platform (for this or for other courses as well). Not surprisingly, the answers provided by the students were overwhelmingly positive, with the majority of the respondents expressing a positive attitude towards the employment of the platform as an aid during and after the English classes. This questionnaire will be used for a subsequent, more detailed study on the usefulness of such platforms from the students' perspective.

\section{Conclusions}

Being in a constant struggle of trying to keep our students' interest during the English class at a time when they are bombarded with technological distractions from every platform and every direction television programmes, smart devices, computers, laptops etc. - requires a teacher's resourcefulness and creativity, and investment of his/her time and money in materials and technology in order to keep up with the pace at which students operate on a daily basis, including in class. This paper has taken a closer look at the employment of technology during the English class with students in Business Administration from the North University Center of Baia Mare, the Technical University of Cluj-Napoca, from a rather personal perspective, describing an approach that is not very common, yet on the rise, reporting an experiment carried out by the author with her groups of students. It was a case study regarding the extent to which the use of technology aids the teaching-learning process at the end of which it was proven that in a technology-driven society, students are more open to technology than they have ever been, being willing to use it in class, as well as outside it with the aim of improving their learning experience, and thus their skills. The whole experiment was also an attempt to find the right balance between traditional teaching-learning tools and the employment of modern technology in class. This final aspect will constitute material for further research, yet one can state that in terms of employing technology during the teaching-learning process, moderation should be the norm, just as it is in any aspect of everyday life. Too much technology employed during the English course leads to eventually getting bored with that particular technology, and thus it misses its purpose. So it should be applied in small increments in order to keep its effectiveness throughout the course. 


\section{References}

Demarcsek, Ramona, Todea, Lumința, Fălăuș, Anamaria, Using the Students' Technical Abilities for the Improvement of the Teaching-Learning Process during the English Course, în "Tehnici și strategii novatoare în dinamica limbajelor de specialite”, Editura Casa Cărții de Știință, 2017, Cluj-Napoca, p. 130-139.

Demarcsek, Ramona, Todea, Lumința, Using Technology as a Tool for Improving the Quality of the Teaching-Learning Experience During the English Class, In Grănescu, M., (ed.), Acta Technica Napocensis, Series: Languages for Specific Purposes, vol. 16, nr. 3, U.T.Press Publishing House, ISSN 1454685X, 2016, Cluj-Napoca, p. 39-48.

Hardison, John, 44 Smart Ways To Use Smartphones in Class, 2013, http://gettingsmart.com/ 2013/01/part-1-44-smart-ways-to-use-smartphonesin-class/

Hennessy, Marcus A., Using Smartphones (And Other PDAs) in Class: These Days it's Cool! http://lessonplanspage.com/using-smartphones-and-other-pdas-inclass-these-days-its-cool/

Hess, Natalie, Teaching Large Multilevel Classes, Cambridge University Press, 2012 Cambridge, UK

Leyden, Andrea, 40 Uses For Smartphones in School, 2015, https://www.examtime.com/blog/40-uses-for-smartphones-in-school/

McKay, Heather, Tom, Aabigail, Teaching Adult Second Language Learners, Cambridge University Press, 2009, Cambridge,UK.

Robinson, Ken, Changing Education Paradigms, 2010.

https://www.ted.com/talks/ken_robinson_changing_education_paradigms 